\title{
Remanufacturing: Strategi dan Desain dalam Rantai Pasok Lingkaran Tertutup
}

\author{
Shu-San Gan ${ }^{*}$, Didik Wahjudi' ${ }^{1}$, Yopi Tanoto ${ }^{1}$ \\ 1,Program Studi Teknik Mesin, Fakultas Teknologi Industri, Universitas Kristen Petra \\ Jl. Siwalankerto 121-131, Surabaya 60236, Indonesia \\ * Penulis korespondensi; E-mail: gshusan@petra.ac.id
}

\begin{abstract}
ABSTRAK
Remanufaktur adalah proses pemulihan barang bekas yang memberikan preservasi tertinggi terhadap nilai tambah produk originalnya, proses ini mentransformasikan barang bekas menjadi "seperti baru" dan seringkali dikembalikan ke pasar dengan garansi yang ekuivalen seperti produk baru. Praktik remanufaktur ini dapat memberikan dampak positif terhadap lingkungan karena dapat mengurangi limbah yang dibuang ke tempat pembuangan akhir. Namun remanufaktur juga memiliki banyak tantangan, tidak hanya dalam aspek teknikal dan operasional, tetapi juga pada aspek strategi dan desain. Makalah ini menyajikan pendekatan konseptual berdasarkan tinjauan literatur untuk menjawab tantangan remanufaktur dalam rantai pasok lingkaran tertutup, serta mengusulkan strategi dan desain implementasinya. Pendekatan yang digunakan adalah qualitative content analysis untuk mengidentifikasi berbagai konsep dan membagi dalam kategori yang sesuai. Hasil analisis menunjukkan bahwa implementasi remanufaktur dalam rantai pasok lingkaran tertutup dapat diterapkan dengan penentuan motif dan pendorong, dimensi keputusan remanufaktur, strategi implementasi remanufaktur, desain produk dan proses, serta desain jaringan.
\end{abstract}

Kata kunci: Remanufaktur, rantai pasok lingkaran tertutup, strategi, desain.

\begin{abstract}
Remanufacturing is the process of recovering used product that provides the highest preservation of the added value of the original product, this process transforms used product into "like new" and is often returned to the market with a warranty equivalent to that of a new product. Remanufacturing can have a positive impact on the environment because it can reduce waste that is disposed to the landfills. However, remanufacturing also has many challenges, not only in technical and operational aspects, but also in strategic and design aspects. This paper presents a conceptual approach based on a literature review to address the challenges of remanufacturing in a closed-loop supply chain and proposes a strategy and design for its implementation. The approach used is qualitative content analysis to identify various concepts and divide them into appropriate categories. The results of the analysis show that the implementation of remanufacturing in a closedloop supply chain can be applied by determining the motives and drivers, dimensions of remanufacturing decisions, remanufacturing implementation strategies, product and process design, and network design.
\end{abstract}

Keywords: remanufacturing, closed-loop supply chain, strategy, design

\section{PENDAHULUAN}

Remanufaktur adalah salah satu proses pemulihan yang memberikan preservasi tertinggi terhadap nilai tambah produk originalnya, dan diberi label sebagai "the ultimate form of recycling" [1]. Beberapa penelitian menunjukkan bahwa remanufaktur adalah proses yang ramah lingkungan, ecoefficient, dan menciptakan nilai ekonomis [2,3]. Penerapan remanufaktur dapat meningkatkan kompleksitas dari manajemen rantai pasok, karena industri sekarang harus juga menangani aliran balik dari rantai pasok, disamping aliran maju yang selama ini telah dilaksanakan. Namun demikian, integrasi dari aliran maju dan aliran balik rantai pasok serta isu manajerial lainnya, yang disebut sebagai closed-loop supply chain dan selanjutnya disebut rantai pasok lingkaran tertutup (RPLT), telah mendapat perhatian dari akademisi. Dalam dua dekade terakhir ini, studi tentang remanufaktur 
dan RPLT ini telah berkembang secara signifikan. Dalam upaya membangun teori pengambilan keputusan secara strategis untuk implementasi remanufaktur, dilakukan tinjauan literatur yang selanjutnya diikuti dengan ajuan strategi dan desain untuk implementasi remanufaktur.

Remanufaktur adalah bagian yang penting dari RPLT karena menimbulkan aliran balik pengembalian produk dari konsumen ke pelaku remanufaktur, dan produk dipulihkan menjadi "seperti baru" untuk kemudian dijual kembali ke pasar. Proses remanufaktur melibatkan testing untuk memastikan hasil proses tersebut menghasilkan produk dengan kualitas yang setara dengan produk barunya. Proses ini dikombinasikan dengan aliran maju produk baru dari bahan baku hingga ke pasar akan membentuk lingkaran tertutup. Pada konteks Indonesia, remanufaktur masih belum banyak diimplementasikan karena keterbatasan jaringan reverse logistics. Eksplorasi terkait rantai pasok lingkaran tertutup menjadi penting dalam perspektif binsis di Indonesia mengingat potensinya yang besar. Oleh karena itu, tujuan dari penelitian ini ada dua. Pertama, menyajikan definisi komprehensif untuk definisi remanufaktur dan RPLT serta menjelaskan relasi antar keduanya. Kedua, menyajikan pendekatan konseptual yang menitikberatkan pada strategi dan desain untuk remanufaktur dalam rantai pasok lingkaran tertutup agar dapat memaksimalkan value creation dan value recovery dari produk bekas yang dikembalikan dari konsumen.

\section{METODE YANG DIGUNAKAN}

Studi ini menggunakan pendekatan tinjauan literatur yang dimulai dengan memilih studi sebelumnya yang menyediakan definisi dari remanufaktur dan rantai pasok lingkaran tertutup. Pemilihan studi tidak dibatasi pada jenis produk atau teknologi manufakturnya karena penulis ingin mendapatkan definisi yang lengkap untuk bahan kajian. Dari hasil ini, dilakukan analisis dan disimpulkan sebuah definisi yang komprehensif. Selanjutnya, dilakukan qualitative content analysis pada makalah-makalah yang mempelajari strategi dan desain remanufaktur dalam kaitannya dengan RPLT. Melalui dua langkah tersebut, diusulkan sebuah pendekatan konseptual yang dapat dijadikan acuan untuk keberhasilan penerapan remanufaktur.

\section{HASIL DAN PEMBAHASAN}

\section{Definisi Remanufaktur}

Definisi yang muncul pada kajian awal remanufaktur berfokus pada upaya mengembalikan produk bekas menjadi "seperti baru". Haynsworth \& Lyons menggambarkan remanufaktur sebagai sebuah proses industrial dimana produk bekas yang sudah usang direstorasi menjadi seperti produk baru [4].
Amezquita dkk. menggunakan terminologi remanufaktur sebagai "merestorasi produk menjadi berkondisi seperti produk baru dengan menggunakan kembali (reusing), melakukan rekondisi (reconditioning), dan menggantikan komponen (repair) [5]. Steinhilper menjabarkan remanufaktur sebagai sebuah proses daur ulang melalui proses manufaktur yang menghasilkan produk yang berkondisi baik seperti baru (good-as-new) dari produk bekas. Ia menyatakan bahwa remanufaktur telah digunakan sebagai terminologi standar dari proses restorasi produk yang tahan lama [1]. Lindahl dkk. juga menggunakan definisi yang serupa [6]. Lund \& Hauser memberikan definisi remanufaktur sebagai proses merestorasi produk non-fungsional, yang sudah dibuang atau ditukar-tambah-kan, menjadi produk berkondisi seperti baru. Selanjutnya, dijelaskan bahwa terminologi "seperti baru" merupakan kunci dari remanufaktur, yang mana dapat dilihat dari sudut pandang produser sebagai intensi, klaim, dan kemampuan untuk membuat produk seperti itu. Dari sudut pandang konsumen, terminologi tersebut merepresentasikan ekspektasi terhadap produk yang dijual dengan label remanufaktur [7].

Ijomah dkk. mengusulkan definisi yang lebih kuat yang didapatkan dari membandingkan definisi Haynsworth \& Lyons dan Amezquita dkk. dengan praktik pada industri melalui studi kasus. Definisi ini dimaksudkan untuk menghindarkan ambigu antara remanufaktur, rekondisi, dan repair. Definisi yang dihasilkan menyatakan bahwa remanufaktur adalah proses mengembalikan produk bekas ke spesifikasi kinerja awal dari Produsen Peralatan Asli (Original Equipment Manufacturer/OEM) dan produk yang dihasilkan memberikan garansi yang setidaknya sama dengan produk baru yang ekuivalen [8]. Definisi ini memungkinkan kondisi dimana produk remanufaktur mempunyai spesifikasi kinerja yang lebih tinggi dari produk originalnya. Dengan demikian, remanufaktur tidak hanya memenuhi standar yang ditentukan produsen tetapi juga memenuhi harapan konsumen dalam hal spesifikasi dan penjaminan mutu. Sundin \& Bras menambahkan deskripsi proses remanufaktur ke definisinya, sehingga remanufaktur didefinisikan sebagai proses untuk pembangunan kembali sebuah produk dimana produk dibersihkan, diinspeksi, dan dibongkar; komponen yang rusak diganti; dan produk dirakit kembali, diuji, dan diinspeksi lagi untuk memastikan produk memenuhi atau melebihi standar produk barunya [9]. Gray \& Charter menambahkan pernyataan preservasi nilai tambah produk dan mendeskripsikan remanufaktur sebagai sebuah proses untuk menangkap kembali nilai tambah yang diberikan ke material saat produk pertama diproduksi [10]. Dengan demikian, proses ini diharapkan menghasilkan pengurangan energi, material dan biaya produksi. 
Selain defnisi yang disajikan oleh akademisi, Automotive Parts Remanufacturer Association (APRA) and The British Standard Institution (BSI) juga menentukan definisinya. Definisi APRA digunakan di Amerika, Eropa, dan Asia bersama CLEPA (European Association of Automotive Suppliers), and FIRM (International Federation of Engine Remanufacturers and Rebuilders, Europe). Menurut APRA: komponen hasil remanufaktur memiliki fungsi yang serupa dengan komponen original; dihasilkan dari restorasi komponen bekas (core) dengan menggunakan proses industri terstandarisasi yang sejalan dengan spesifikasi teknis tertentu. Komponen remanufaktur menyediakan garansi yang sama seperti komponen barunya, dan harus mengidentifikasikan dengan jelas status remanufaktur serta peremanufakturnya. BSI memberikan definisi remanufaktur sebagai proses mengembalikan produk bekas ke kondisi yang sedikitnya sama dengan kinerja awalnya dengan garansi yang ekuivalen atau lebih baik daripada produk barunya. Definisi terbaru disajikan oleh United Nations Environment Programme dimana remanufaktur adalah proses industri terstandarisasi yang dilakukan dalam pengaturan industri atau pabrik, yang mana produk bekas direstorasi menjadi berkondisi serta berkinerja seperti atau bahkan lebih dari produk barunya; proses remanufaktur harus memenuhi spesifikasi teknis tertentu, termasuk rekayasa, kualitas, standar pengujian, dan memberikan garansi penuh [11]. Tampak bahwa para akademisi dan praktisi memiliki pemahaman yang konsisten terkait konsep remanufaktur.

Dari berbagai definisi di atas yang memiliki berbagai penekanan, maka disimpulkan sebuah definisi yang komprehensif sebagai berikut: Remanufaktur adalah proses restorasi produk bekas dengan menangkap kembali nilai tambah yang diberikan saat produk pertama kali diproduksi; dimana produk bekas direkondisi untuk menghasilkan produk seperti baru dengan spesifikasi kinerja yang sama atau lebih tinggi dari produk barunya, baik dari perspektif konsumen maupun peremanufaktur; memberikan garansi yang ekuivalen dengan produk barunya; serta memberikan pelabelan yang jelas atas status sebagai produk remanufaktur dan pihak premanufakturnya.

\section{Definisi dari Rantai Pasok Lingkaran Ter- tutup (RPLT)}

Pada umumnya, definisi rantai pasok lingkaran tertutup berfokus pada penggabungan rantai pasok aliran maju dan aliran balik. Guide dkk. menggambarkan RPLT sebagai rantai pasok yang dirancang untuk mempertimbangkan tidak hanya proses aliran maju yang tradisional, namun juga proses yang diperlukan untuk pengembalian produk [12]. Kegiatan tambahan pada aliran balik ini adalah akuisisi produk bekas; logistik aliran balik; tes/uji, sortir, dan inspeksi; proses pemulihan - direct reuse, perbaikan, remanufaktur, dan daur ulang-serta pembuangan; juga remarketing. Ferguson \& Souza mendefinisikan RPLT sebagai rantai pasok dimana selain aliran material yang tipikal dari penyuplai ke konsumen, terdapat aliran produk kembali dari konsumen ke pemanufaktur [13]. Pochampally dkk [14] dan Lebreton [15] menyajikan definisi atau deskripsi yang serupa. Lebih lanjut lagi, Blanc [16] dan Guide \& Wassenhove [17] tidak hanya mempertimbangkan rantai pasok aliran maju dan balik beserta aktivitas pada aliran balik, melainkan juga seluruh proses bisnis yang terlibat.

Dari definisi-definisi yang telah disajikan, dapat disimpulkan deskripsi yang paling baik untuk menggambarkan rantai pasok lingkaran tertutup sesuai definisi dari Guide \& Wassenhove yaitu: Manajemen rantai pasok lingkaran tertutup adalah perancangan, pengendalian, dan pengoperasian sebuah sistem untuk memaksimalkan value creation selama seluruh siklus hidup produk dengan pemulihan nilai yang dinamis dari berbagai jenis dan volume pengembalian dari waktu ke waktu.

\section{Remanufaktur dalam Konteks Rantai Pasok Lingkaran Tertutup}

Rantai pasok lingkaran tertutup mengimplikasikan kebutuhan untuk melakukan aktivitas pemulihan dalam rangka menutup lingkaran rantai pasok. Thierry dkk. [18] memberikan beberapa opsi proses pemulihan yang dapat digunakan dalam RPLT yang meliputi repair, refurbishing, remanufacturing, cannibalization, dan recycling. Sedangkan untuk jenis pengembalian (produk bekas yang dikembalikan), de Brito \& Dekker [19] mengklasifikasikan pengembalian ke dalam tiga kategori yaitu pengembalian dari manufaktur, distribusi dan konsumen. Pengembalian dari manufaktur terdiri dari kelebihan bahan baku, pengembalian dari pengendalian kualitas, dan kelebihan produksi atau produk sampingan. Pengembalian dari distribusi termasuk penarikan produk, pengembalian komersial business to business (B2B), penyesuaian stok dan pengembalian fungsional. Sedangkan pengembalian konsumen bisa berasal dari pengembalian business to consumer (B2C), bisa berasal dari garansi, servis, atau produk yang dikembalikan saat mencapai akhir masa pakainya (EOU returns) dan saat mencapai akhir umur produk (EOL returns). Berdasarkan pengalaman mereka di industri, Guide \& Wassenhove [20] mengusulkan model pasangan dominan antara jenis pengembalian konsumen dengan aktivitas pemulihan yang spesifik. B2C consumer returns dipasangkan dengan proses perbaikan ringan; EOU returns dipasangkan dengan kegiatan remanufaktur; sdangkan EOL returns yang biasanya telah obsolet secara teknologi dan seringkali sudah usang, dipasangkan dengan pemulihan komponen dan daur ulang. 
Proses pemulihan yang menginisasi sebuah RPLT dapat diterapkan tidak hanya ke pengembalian konsumen, tetapi juga pada pengembalian distribusi. B2B commercial returns dari produk tidak terjual atau produk yang rusak saat pengiriman dapat dipulihkan dengan proses perbaikan atau remanufaktur sebelum didistribusikan ulang. B2C consumer returns yang diterima tidak jauh dari fase decline siklus pemasaran produk dan dekat dengan fase perkenalan model baru, dipasangkan dengan proses refurbishing dan remanufaktur sebelum dipasarkan kembali, mengingat gagasan upgrade dibutuhkan untuk bersaing dengan model yang lebih baru. EOU returns dapat ditingkatkan melalui proses refurbishing dan remanufaktur karena terdapat segmen pasar yang lebih menyukai produk refurbishing dengan harga yang lebih rendah dibandingkan produk remanufaktur. EOL returns dapat digunakan untuk proses kanibalisasi komponen atau daur ulang sebelum dikembalikan ke siklus manufaktur.

Dari diskusi di atas dapat disimpulkan bahwa remanufaktur adalah bagian dari rantai pasok lingkaran tertutup sebagaimana ditunjukkan pada Gambar 1. Isu yang muncul dari masalah remanufaktur tidak selalu terkait dengan RPLT karena dapat isu yang difokuskan pada proses pemulihan dari sudut pandang pelaku remanufaktur, tanpa mempertimbangkan keseluruhan rantai pasok. Namun, keberhasilan implementasi remanufaktur sangat bergantung pada akuisisi produk bekas yang dipengaruhi oleh aliran balik RPLT. Demikian pula pemasaran ulang yang merupakan salah satu aspek dalam RPLT, merupakan salah satu faktor utama yang mempengaruhi keberhasilan implementasi remanufaktur.

Mengingat definisi RPLT yang diberikan oleh Guide \& Wassenhove [17], dimana RPLT berfokus pada value creation sepanjang seluruh siklus hidup produk, maka remanufaktur menjadi proses utama untuk pemulihan produk. Hal ini terjadi karena remanufaktur dapat mengembalikan produk bekas ke spesifikasi kinerja yang setidaknya ekuivalen dengan produk barunya, lengkap dengan garansi; sehingga menunjukkan value creation tertinggi melalui rekondisi dan upgrade.

\section{Strategi}

\section{Motif dan Pendorong}

Ada tiga motif dari perusahaan untuk melaksanakan remanufaktur, yaitu regulasi, tanggung jawab moral, dan profitabilitas [21]. Namun demikian, dari studi kasus yang dilakukan terhadap industri remanufaktur mesin otomotif, Seitz menemukan bahwa faktor yang paling berpengaruh adalah pasokan suku cadang yang aman, sumber garansi, pangsa pasar, dan proteksi merk. Kumar \& Putnam [22] menemukan bahwa dalam industri otomotif, peralatan rumah tangga dan elektronik, faktor yang berpengaruh adalah kompetisi pasar, peraturan, dan pertumbuhan globalisasi. Profitabilitas adalah motif penting yang dapat mendorong penerapan remanufaktur. Sebuah perusahaan dapat memperoleh keunggulan kompetitif dengan memperkenalkan product take back dan remanufaktur; dan manfaat yang dipengaruhi derajat subsitusi produk serta sensitivitas harga [23]. Saat perusahaan memilih orientasi keuntungan dalam manajemen pemulihan produk, maka ia haruslah meningkatkan level pemulihan [24]. Peraturan tentang lingkungan dapat meningkatkan profitabilitas melalui penerapan remanufaktur. Dalam peraturan penarikan produk WEEE (Waste Electrical and Electronic Equipment) yang berlaku di Eropa, pemerintah memegang kendali atas pengembalian produk, oleh karena itu penarikan produk WEEE secara kolektif dipandang lebih menguntungkan [25]. Remanufaktur dan RPLT yang membentuk green image perusahaan juga dapat menjadi pendorong untuk menaikkan harga saham perusahaan [26].

Dapat disimpulkan bahwa profitabilitas memegang peran yang signifikan dalam mendorong perusahaan untuk terlibat dalam remanufaktur.

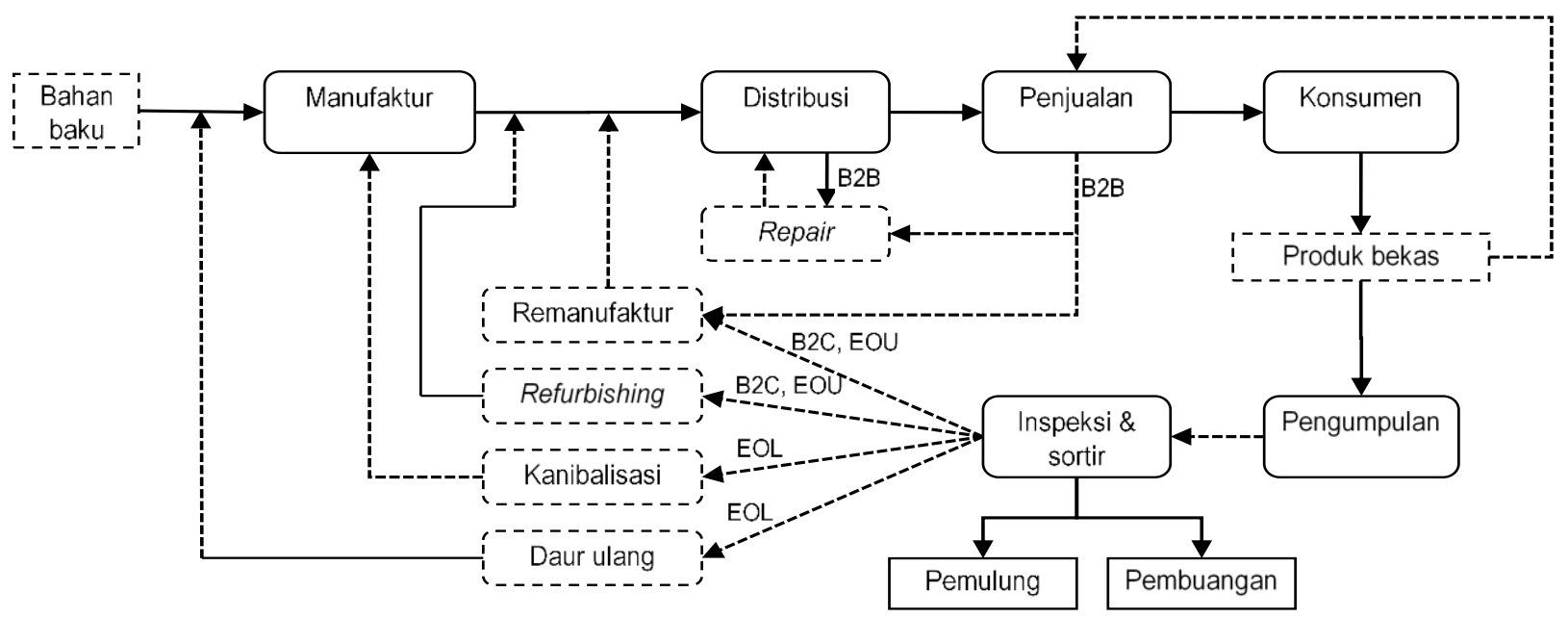

Gambar 1. Remanufaktur sebagai bagian dari rantai pasok lingkaran tertutup 
Meskipun beberapa perusahaan mempunyai perhatian dalam hal keberlanjutan dan perlindungan lingkungan, namun tetap harus memperhatikan beban biaya langsung maupun tidak langsung. Di sisi lain, perusahaan juga ada yang harus menerapkan RPLT sebagai bentuk kepatuhan pada peraturan pemerintah. Oleh karena itu, agar remanufaktur dapat diterapkan dengan baik, haruslah ditentukan pendekatan yang menguntungkan perusahaan, baik yang tangible (seperti peningkatan penjualan akibat sentimen positif konsumen terhadap green image perusahaan, dan kepercayaan atas kualitas produk remanufaktur) maupun intangible (seperti reputasi perusahaan yang mendukung keberlanjutan, melindungi lingkungan, dan taat pada peraturan pemerintah).

\section{Keputusan untuk Melakukan Remanufaktur}

Sebelum memutuskan untuk melakukan remanufaktur, sebuah perusahaan perlu melakukan eksplorasi dan melakukan penilaian apakah remanufaktur dapat menjadi strategi operasional untuk mencapai target jangka panjang. Debo dkk. [27] memberikan dua dimensi terkait hal tersebut yaitu segmentasi pasar dan pemilihan teknologi produk. Dimensi ini sangat kuat keterkaitannya dengan kebergantungan pada ketersediaan pasokan bahan remanufaktur, yaitu dari penjualan produk barunya. Pada remanufaktur mesin otomotif, keputusan untuk melakukan remanufaktur lebih utama didorong oleh isu teknis daripada isu ekonomis atau lingkungan [28]. Dimensi ketiga adalah kanibalisasi, dimana saat perusahaan menghindari kanibalisasi internal produk bekas maka pihak ketiga dapat mengambil alih peran tersebut dan melakukan remanufaktur sehingga memunculkan kompetisi eksternal. Ferguson \& Toktay [29] menyusun sebuah model yang menganalisis kompetisi internal antara produk baru dan produk remanufaktur dalam kondisi monopolis. Dimensi yang keempat adalah persepsi konsumen, yang berelasi secara positif dengan kesediaan membayar (willingness to pay/WTP) [30].

Keputusan untuk terlibat dalam remanufaktur juga dipelajari dari pendekatan empiris. Kapetanopoulou \& Tagaras [30] menemukan bahwa jenis perusahaan dapat mempengaruhi keputusan ini, dimana faktor-faktor yang mempengaruhi OEM berbeda dari peremanufaktur independen. Beberapa kerangka kerja yang mendukung pengambilan keputusan untuk melakukan remanufaktur disajikan oleh Subramoniam dkk [31] dalam bidang automotive aftermarket, dan Kuik dkk. [32] untuk collaborative manufacturing.

\section{Strategi Implementasi Remanufaktur}

Analisis strategi untuk implementasi remanufaktur diawali dari studi perilaku RPLT. Isu lingkungan seperti green image perusahaan dapat memberikan pengaruh pada permintaan konsumen; kewajiban take back dan kampanye pembuangan produk bekas secara benar dapat mempengaruhi perilaku RPLT, dan pada akhirnya mempengaruhi strategi kapasitas remanufaktur [33]. Sebuah model sistem dinamis untuk remanufaktur dalam RPLT disajikan oleh Vlachos dkk. [34] dengan mempertimbangkan beberapa hal di atas, dan mengusulkan kebijakan yang efisien untuk kapasitas remanufaktur dan pengumpulan, yaitu menggunakan keuntungan total rantai pasok sebagai ukuran keefektifan kebijakan.

Investasi diperlukan untuk membangun dan meningkatkan sistem remanufaktur, seperti meningkatkan reusability produk, meningkatkan kapasitas pengumpulan produk bekas dan proses remanufaktur. Namun demikian, tantangan dalam keputusan investasi yang dipicu oleh kualitas pengembalian yang rendah, ditentukan oleh kemampuan perusahaan untuk melakukan inspeksi dan teknologi yang dimiliki, serta parameter pasar [34]. Kebijakan fleksibel, yaitu ekspansi kapasitas secara bertahap, dipandang lebih baik dibandingkan mengambil investasi besar di awal, terutama saat menghadapi ketidakpastian permintaan pasar, pola penjualan, kualitas dan waktu pengembalian [35].

Keseimbangan suplai dan permintaan adalah salah satu problem mendasar dalam manajemen rantai pasok. Hal ini juga sangat penting dalam RPLT dengan remanufaktur, dimana permintaan pasar dipengaruhi oleh persepsi konsumen terhadap produk hasil proses pemulihan, dan terdapat tidakpastian dalam pengembalian produk, baik secara kuantitas maupun kualitas. Sebuah perusahaan seharusnya memperlakukan pengembalian sebagai value stream daripada waste stream, dan mempertimbangkan keseluruhan rantai pasok untuk menghindari bottleneck [36]. Waktu pengembalian dan kualitasnya bergantung pada jenis produk, dan tingkat pengembalian yang dipengaruhi antara lain oleh umur produk, laju inovasi teknologi, dan laju kegagalan komponen [37].

Kolaborasi dan relasi dalam rantai pasok juga merupakan strategi penting untuk keberhasilan implementasi remanufaktur. Beberapa relasi yang ada dalam rantai pasok adalah relasi berbasis kepemilikan, berbasis kontrak, pemesanan langsung, berbasis deposit, berbasis kredit, buy-back, dan berbasis sukarela. Selain itu perusahaan dapat mengambil keputusan untuk bersaing atau bekerjasama dalam melaksanakan remanufaktur, atau memilih outsourcing kegiatan remanufaktur [38]. Pada pelaksanaan outsourcing, perusahaan tetap memperhatikan hasil proses pemulihan yang sesuai dengan karakteristik produk remanufaktur, yaitu "seperti baru" dan diberikan garansi setara dengan produk barunya.

\section{Desain}

\section{Desain Produk dan Proses}

Saat perusahaan telah memutuskan untuk terlibat dalam remanufaktur, maka perlu merancang proses remanufaktur dan mengambil keputusan 
terkait pemilihan teknologi yang berpengaruh secara finansial. Mengintegrasikan pemilihan teknologi kedalam keputusan investasi dapat mempengaruhi nilai waktu biaya [39]. Jiang dkk. [40] menyajikan pembahasan komprehensif terkait pemilihan teknologi remanufaktur, dimana ada enam kriteria pengambilan keputusan yaitu biaya, kualitas, waktu, layanan, konsumsi sumber daya, dan dampak lingkungan. Ada dua faktor yang mempengaruhi desain produk yaitu siklus upgrade dan disassemblability. Potensi remanufaktur harus diintegrasikan seawal mungkin dalam proses desain [41], dan meliputi desain modular, proses rantai pasok aliran balik, dan penentuan jumlah dan durasi siklus untuk penggunaan berulang kali serta kemungkinan upgrade. Di sisi lain, strategy desain produk yang efektif untuk OEM saat bersaing dengan peremanufaktur adalah dengan mengambil keputusan keseimbangan antara desain produk dan harga [42]. Saat derajat disassemblability tinggi, biaya produksi OEM berkurang namun biaya pemulihan peremanufaktur juga lebih rendah sehingga potensi menyaingi produk baru OEM menjadi lebih tinggi. Oleh karena itu diperlukan keputusan optimal.

Dong dkk. [43] menunjukkan bahwa teknologi laser dapat memecahkan masalah sulit dalam pemeliharaan dan remanufaktur peralatan. Untuk pengembangan lebih lanjut, terdapat beberapa masalah utama yaitu tingginya kebutuhan daya sistem laser, teknik laser untuk remanufaktur, dukungan dari pemerintah dan perusahaan. Teknologi canggih lain yang digunakan dalam remanufaktur adalah Robotic High Pressure Cold Spray (HPCS) untuk merestorasi permukaan yang aus, Automated Adaptive Machining untuk memperbaiki komponen [44]. Selain itu, perkembangan revolusi industri 4.0 juga mempengaruhi teknologi remanufaktur khususnya dalam penggunaan teknologi digital untuk mempersingkat dan meningkatkan relasi antara produsen, pengguna, dan peremanufaktur [45].

\section{Desain Jaringan}

Jaringan remanufaktur dalam rantai pasok lingkaran tertutup terdiri dari dua jalur. Yang pertama berfokus pada jaringan pengumpulan produk bekas, karena ini merupakan kebutuhan utama sebagai bahan baku proses remanufaktur. Desain jaringan untuk remanufaktur pada umumnya bertujuan meminimalkan biaya. Lee \& Chan [46] menyajikan penggunaan RFID dalam memilih lokasi optimal pusat pengumpulan. Ji [47] mengusulkan pendekatan yang lebih komprehensif daam pemilihan lokasi pusat pengumpulan, yaitu dengan mempertimbangkan kesejahteraan sosial masyarakat sekitar, keuntungan penyedia proses pemulihan, surplus konsumen, perlindungan lingkungan, dan biaya pemerintah.

Jalur kedua berfokus pada jaringan pengumpulan dan fasilitas pemulihan secara terintegrasi. Srivastava [48] menyusun kerangka modeling untuk desain jaringan yang melibatkan pusat pengumpulan, perbaikan, refurbishing, dan remanufaktur, namun mendapatkan bahwa remanufaktur bukanlah proposisi yang menguntungkan secara ekonomis. Dalam penelitian lain, ditemukan bahwa ukuran jaringan, lokasi fasilitas, kapasitas manufaktur dan remanufaktur, serta struktur pasar menjadi faktor yang dapat memberikan pengaruh kuat dalam pemilihan desain jaringan serta memperbaiki harapan keutungan $[49,50]$.

\section{Kerangka strategi dan desain}

Dari analisis konten secara kualitatif terhadap literatur terkait remanufaktur dan RPLT maka diusulkan kerangka strategi dan desain yang dapat menjadi acuan untuk implementasi remanufaktur, seperti ditunjukkan pada Gambar 2.

\begin{tabular}{|c|c|c|c|c|}
\hline $\begin{array}{l}\text { Motif dan } \\
\text { Pendorong }\end{array}$ & $\begin{array}{l}\text { Tangible: } \\
\text { Perluasan } \\
\text { pasar }\end{array}$ & $\begin{array}{l}\text { Intangible: } \\
\text { Reputasi } \\
\text { Lingkungan } \\
\text { Regulasi }\end{array}$ & & \\
\hline $\begin{array}{l}\text { Dimensi } \\
\text { Keputusan }\end{array}$ & $\begin{array}{l}\text { Segmentasi } \\
\text { pasar }\end{array}$ & $\begin{array}{l}\text { Teknologi } \\
\text { produk }\end{array}$ & $\begin{array}{c}\text { Efek } \\
\text { kanibalisasi }\end{array}$ & $\begin{array}{c}\text { Persepsi } \\
\text { konsumen dan } \\
\text { WTP }\end{array}$ \\
\hline $\begin{array}{c}\text { Strategi } \\
\text { mplementasi }\end{array}$ & $\begin{array}{c}\text { Kapasitas } \\
\text { remanufaktur }\end{array}$ & $\begin{array}{l}\text { Kebijakan } \\
\text { investasi }\end{array}$ & $\begin{array}{l}\text { Keseimbangan } \\
\text { suplai dan } \\
\text { permintaan }\end{array}$ & $\begin{array}{l}\text { Kolaborasi dan } \\
\text { relasi dalam } \\
\text { rantai pasok }\end{array}$ \\
\hline $\begin{array}{c}\text { Desain } \\
\text { produk \& } \\
\text { proses }\end{array}$ & $\begin{array}{c}\text { Teknologi } \\
\text { remanufaktur }\end{array}$ & $\begin{array}{c}\text { Desain produk } \\
\text { untuk } \\
\text { remanufaktur }\end{array}$ & $\begin{array}{l}\text { Teknologi } \\
\text { digital Revolusi } \\
\text { Industri } 4.0\end{array}$ & \\
\hline $\begin{array}{l}\text { Desain } \\
\text { jaringan }\end{array}$ & $\begin{array}{c}\text { Jaringan } \\
\text { pengumpulan } \\
\text { barang bekas }\end{array}$ & $\begin{array}{c}\text { Jaringan } \\
\text { fasilitas } \\
\text { pemulihan }\end{array}$ & $\begin{array}{l}\text { Integrasi } \\
\text { jaringan aliran } \\
\text { maju dan balik }\end{array}$ & \\
\hline
\end{tabular}

Gambar 2. Kerangka strategi dan desain untuk implementasi remanufaktur dalam RPLT 


\section{KESIMPULAN}

Studi tentang remanufaktur dalam rantai pasok lingkaran tertutup telah berkembang dalam dua dekade terakhir ini, terutama dalam rangka menjawab tuntutan keberlanjutan dan dampak lingkungan. Implementasi remanufaktur bukanlah keputusan yang mudah bagi perusahaan, karena ada banyak aspek yang harus dipertimbangkan. Melalui tinjauan literatur telah disajikan analisis konten secara kualitatif sehingga dapat dikupas faktorfaktor yang berpengaruh dan perlu diperhatikan, serta temuan yang telah disajikan melalui penelitian sebelumnya. Hasil analisis menunjukkan bahwa implementasi remanufaktur dalam rantai pasok lingkaran tertutup dapat diterapkan dengan penentuan motif dan pendorong, dimensi keputusan remanufaktur, strategi implementasi remanufaktur, desain produk dan proses, serta desain jaringan. Kajian ini terbatas pada aspek strategi dan desain, dan dapat dikembangkan pada penelitian berikutnya untuk mencakup aspek teknis operasional dan pemasaran.

\section{DAFTAR PUSTAKA}

[1]. Steinhilper, R., 1998. "Remanufacturing - The Ultimate Form of Recycling", Fraunhofer IRB Verlag.

[2]. Guide, V.D.R.J., Teunter, R.H. \& Wassenhove, L.N. Van, 2003. "Matching Demand and Supply to Maximize Profits from Remanufacturing". Manufacturing \& Service Operations Management, 5(4), pp. 303-316.

[3]. Neto, J.Q.F. \& Bloemhof-Ruwaard, J.M., 2012. An Analysis of the Eco-Efficiency of Personal Computers and Mobile Phones. Production and Operations Management, 21(1), pp.101-114.

[4]. Haynsworth, H.C. \& Lyons, R.T., 1987. "Remanufacturing by design, the missing link". Production and Inventory Management, 2, pp.24-28.

[5]. Amezquita, T., Hammond, R., Salazar, M. and Bras, B., 1995, September. Characterizing the remanufacturability of engineering systems. In International Design Engineering Technical Conferences and Computers and Information in Engineering Conference (Vol. 17162, pp. 271278). American Society of Mechanical Engineers.

[6]. Lindahl, M., Sundin, E. \& Ostlin, J., 2006. "Environmental Issues within the Remanufacturing Industry". In 13th CIRP International conference on Life Cycle Engineering, Leuven. pp. 447-452.

[7]. Lund, R.T. and Hauser, W.M., 2010, January. Remanufacturing-an American perspective. In 5th International Conference on Responsive Manufacturing-Green Manufacturing (ICRM 2010) (pp. 1-6). IET.
[8]. Ijomah, W.L., Childe, S. \& McMahon, C., 2004. "Remanufacturing: A Key Strategy for Sustainable Development". In Proceedings of the 3rd International Conference on Design and Manufacture for Sustainable Development, 1-2 September, 2004, Loughborough, UK.

[9]. Sundin, E. \& Bras, B., 2005. "Making functional sales environmentally and economically beneficial through product remanufacturing". Journal of Cleaner Production,13, pp.913-925.

[10]. Gray, C. \& Charter, M., 2008. "Remanufacturing and Product Design". International Journal of Product Development, 6(3-4), pp.375-392.

[11]. Nasr, N., Russell, J., Bringezu, S., Hellweg, S., Hilton, B., Kreiss, C. and Von Gries, N., 2018. "Re-defining Value-The Manufacturing Revolution". Remanufacturing, Refurbishment, Repair and Direct Reuse in the Circular Economy.

[12]. Guide, V.D.R.J., Jayaraman, V. \& Linton, J.D., 2003. "Building contingency planning for closedloop supply chains with product recovery". Journal of Operations Management, 21, pp.259-279.

[13]. Ferguson, M.E. \& Souza, G.C., 2010. "Closedloop supply Chains - New Developments to Improve the Sustainability of Business Practices", CRC Press.

[14]. Pochampally, K.K., Nukala, S. \& Gupta, S.M., 2009. "Strategic Planning Models for Reverse and Closed-Loop Supply Chain", CRC Press.

[15]. Lebreton, B., 2007. "Strategic Closed-Loop Supply Chain Management". In Lecture Notes in Economics and Mathematical Systems 586. Springer Berlin Heidelberg, pp. 1-158.

[16]. Le Blanc, H.M., 2006. Closing loops in supply chain management: Designing reverse supply chains for end-of-life vehicles. Tilburg University, School of Economics and Management.

[17]. Guide, V.D.R.J. \& Wassenhove, L.N. Van, 2006. "Closed-Loop Supply Chains: An Introduction to the Feature Issue (Part 1)". Production and Operations Management, 15(3), pp.345-350.

[18]. Thierry, M. et al., 1995. "Strategic issues in product recovery management". California Management Review, 37(2), pp.114-135.

[19]. De Brito, M.P. \& Dekker, R., 2003. "Modelling product returns in inventory control — exploring the validity of general assumptions". International Journal of Production Economics, 81-82, pp.225-241.

[20]. Guide, V.D.R.J. \& Wassenhove, L.N. Van, 2009. "The Evolution of Closed-Loop Supply Chain Research". Operations Research, 57(1), pp.1018.

[21]. Seitz, M.A. \& Wells, P.E., 2006. "Challenging the implementation of corporate sustainability The case of automotive engine". Business Process Management Journal, 12(6), pp.822-836. 
[22]. Kumar, S. \& Putnam, V., 2008. "Cradle to cradle: Reverse logistics strategies and opportunities across three industry sectors". International Journal of Production Economics, 115(2), pp. 305-315.

[23]. Heese, H.S. et al., 2005. "Competitive advantage through take-back of used products". European Journal of Operational Research, 164(1), pp. 143-157.

[24]. Inderfurth, K., 2005. "Impact of uncertainties on recovery behavior in a remanufacturing environment - A numerical analysis". International Journal of Physical Distribution \& Logistics Management, 35(5), pp.318-336.

[25]. Webster, S. \& Mitra, S., 2007. "Competitive strategy in remanufacturing and the impact of take-back laws". Journal of Operations Management, 25, pp.1123-1140.

[26]. Bose, I. \& Pal, R., 2012. "Do green supply chain management initiatives impact stock prices of firms?" Decision Support Systems, 52(3), pp.624-634.

[27]. Debo, L.G., Toktay, L.B. \& Wassenhove, L.N. Van, 2005. "Market Segmentation and Product Technology Selection for Remanufacturable Products". Management Science, 51(8), pp.11931205.

[28]. Seitz, M.A. \& Wells, P.E., 2006. "Challenging the implementation of corporate sustainability The case of automotive engine". Business Process Management Journal, 12(6), pp.822-836.

[29]. Ferguson, M.E. \& Toktay, L.B., 2006. “The Effect of Competition on Recovery Strategies". Production and Operations Management, 15(3), pp. 351-368.

[30]. Kapetanopoulou, P. \& Tagaras, G., 2009. "An empirical investigation of value-added product recovery activities in SMEs using multiple case studies of OEMs and independent remanufacturers". Flexible Services and Manufacturing Journal, 21, pp.92-113.

[31]. Subramoniam, R., Huisingh, D. \& Chinnam, R.B., 2010. "Aftermarket remanufacturing strategic planning decision-making framework: theory \& practice". Journal of Cleaner Production, 18(16-17), pp.1575-1586.

[32]. Kuik, S.S., Nagalingam, S.V. \& Amer, Y., 2011. "Sustainable supply chain for collaborative manufacturing". Journal of Manufacturing Technology Management, 22(8), pp.984-1001.

[33]. Georgiadis, P. \& Vlachos, D., 2004. "The effect of environmental parameters on product recovery". European Journal of Operational Research, 157(2), pp.449-464.

[34]. Robotis, A., Boyaci, T. \& Verter, V., 2012. "Investing in reusability of products of uncertain remanufacturing cost: The role of inspection capabilities". International Journal of Production Economics, 140(1), pp.385-395.
[35]. Georgiadis, P. \& Athanasiou, E., 2013. "Flexible long-term capacity planning in closed-loop supply chains with remanufacturing". European Journal of Operational Research, 225(1), pp.4458.

[36]. Guide, V.D.R.J., Muyldermans, L. \& Wassenhove, L.N. Van, 2005. "Hewlett-Packard Company Unlocks the Value Potential from TimeSensitive Returns". Interfaces, 35(4), pp.281293.

[37]. Ostlin, J., Sundin, E. \& Bjorkman, M., 2009. "Product life-cycle implications for remanufacturing strategies". Journal of Cleaner Production, 17(11), pp.999-1009.

[38]. Ordoobadi, S.M., 2009. "Outsourcing reverse logistics and remanufacturing functions: a conceptual strategic model". Management Research News, 32(9), pp.831-845.

[39]. Kleber, R., 2006. "The integral decision on production/ remanufacturing technology and investment time in product recovery". OR Spectrum, 28, pp.21-51.

[40]. Jiang, Z., Zhang, H. \& Sutherland, J.W., 2011. "Development of multi-criteria decision making model for remanufacturing technology portfolio selection”. Journal of Cleaner Production, 19(1718), pp.1939-1945.

[41]. Pialot, O., Millet, D. \& Tchertchian, N., 2012. "How to explore scenarios of multiple upgrade cycles for sustainable product innovation: the "Upgrade Cycle Explorer" tool". Journal of Cleaner Production, 22(1), pp.19-31.

[42]. Wu, C.-H., 2013. "OEM product design in a price competition with remanufactured product". Omega, 41, pp.287-298.

[43]. Dong, S., Xu, B., Wang, Z., Ma, Y. and Liu, W., 2008, January. "Laser remanufacturing technology and its applications". In Lasers in Material Processing and Manufacturing III (Vol. 6825, p. $68251 N)$. International Society for Optics and Photonics.

[44]. Yeo, N.C.Y., Pepin, H. and Yang, S.S., 2017. "Revolutionizing technology adoption for the remanufacturing industry". Procedia CIRP, 61, pp.17-21.

[45]. Kerin, M. and Pham, D.T., 2020. "Smart remanufacturing: a review and research framework”. Journal of Manufacturing Technology Management, 31(6), pp.1205-1235.

[46]. Lee, C.K.M. \& Chan, T.M., 2009. "Development of RFID-based Reverse Logistics System". Expert Systems With Applications, 36(5), pp.9299-9307.

[47]. Ji, G., 2011. "Effective Implementation of WEEE Take-back Directive: What Types of Take-back Network Patterns in China". Systems Engineering Procedia, 2, pp.366-381.

[48]. Srivastava, S.K., 2008. "Value recovery network design for product returns". International Journal of Physical Distribution \& Logistics Management, 38(4), pp.311-331. 
[49]. Francas, D. \& Minner, S., 2009. "Manufacturing network configuration in supply chains with product recovery". Omega, 37(4), pp.757-769.
[50]. Alumur, S.A. et al., 2012. "Multi-period reverse logistics network design". European Journal of Operational Research, 220(1), pp.67-78. 